I-

〔Nippon Nôgeikagaku Kaishi

Vol.59, No. 5, pp. 519 522, 1985]

牛乳の熱安定性：カゼインミセルの $\mathrm{Ca}$ 塩の形態と $\boldsymbol{r}$-カセ゚インA型との関係

\section{宮辺豊紀，友井弘二 （香川大学農学部食品学科）}

昭和 59 年 8 月 20 日受理

\section{Heat-Stability of Cow Milk : Relationship between Calcium-Salts Formed and $\gamma$-Casein A in Casein Micelle \\ Toyoki MIYABE and Koji TOMOI Department of Food Science, Faculty of Agriculture, Kagazea University, Miki-cho, Kagawa-ken 761.07}

Milk heat-stability increased with a pH-rise when heated to $123^{\circ} \mathrm{C}$ at $\mathrm{pH}$ of 6.4 to 7.2 . As the content of colloidal calcium phosphate $\left[\mathrm{Ca}_{3}\left(\mathrm{PO}_{4}\right)_{2}\right]$ in micelle increased in parallel with a $\mathrm{pH}$-rise, this calcium salt seemed to have an action of dissociating the casein micelle. It seemed that the portion of the peptide chain (unknown substance) containing 4 molecules of Ser-P, which was produced when $\beta$-casein was changed to $\gamma$-casein, associated to $\alpha_{\mathrm{g}}$-casein, contributed to the combination of calcium phosphate, and fulfilled a role to keep the stable micelle structure. Addition of $\gamma$-casein $A$ to type-B milk further increased calcium phosphate in micelle and presumably formed a complicated caseinate complex. The conversion of type-B milk into type-A milk by $\gamma$-casein A seemed to be due to the reduction of calcium phosphate and $\kappa$-casein.

(Received August 20, 1984)

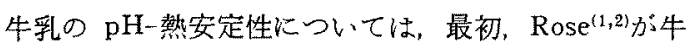
乳の $\mathrm{pH}$ と熱安定性の間に重要な関係があることを見 出して以来，数多くの報告(3-8)が行わ机ている．牛乳の 熱安定性については，Fox \& Morrissey ${ }^{(9)}$ の総説があ る. 牛乳には $\mathrm{pH} 6.4 \sim 7.4$ の煐い範囲に和いて， $\mathrm{pH}$ 6.9 付近で，熱不安定となる $\mathrm{A}$ 型乳と $\mathrm{pH}$ の上昇ととも
に熱安定性が漸次，上昇する B型乳とがある・ケーカゼイ ンA型は， $\mathrm{Ca}^{2+}-$ insensitive といわれている(10)が，詳細 は不明である。また, $\gamma$ ーカゼインは, $\beta$ ーカゼインの分解に より生成する(11 13). 著者らは，B型乳にアーカゼインAを 添加すると，A型乳に転換するという新しい現象を見出 した、B型乳括よび $\gamma$ カガインを添加した場合，上記の $\mathrm{pH}$ 範囲で, 自然状態の生乳中のカぜインミセルの $\mathrm{Ca}$ 塩の形態とカゼイン成分がどのように変化して，熱安定 性に影響を及ぼしているかについて調べたので報告す る.

実験方法 正カセ゚インAはホルスタイン種の個体 乳上り分離・精製(14)し，4 M 尿素・ディスク電気泳動 法(15,16)とデンシトロールにより純度を確認し，100\% 純 粋であった，個体乳の $60 \%$ 以上が $\mathrm{A}_{2}$ 型といわれてい る(11)ので， $\mathrm{A}_{2}$ 型の可能性が高い. 牛乳の熱安定試験は, ホルスタイン種の約 300 頭の混合乳を用いた. $r$-A I $\mathrm{mg}$ をトリス緩衝液 $0.1 \mathrm{ml}$ に溶解して, 脱脂乳 $1 \mathrm{ml}$ K 加えた. $123^{\circ} \mathrm{C}, 1.2$ 気压のオートクレーブで加熱して測 定した。 カゼインミセルの分画は，セファデックス G150 のゲル濾過 $\left(2.5 \times 30 \mathrm{~cm}\right.$ カラム， $4^{\circ} \mathrm{C}$ ，試料釈 10 $\mathrm{ml})$ を行い，水を溶媒とした(17)， $\gamma$-A の添加割合は，上 記と同じである。宮辺ら ${ }^{(17)}$ は，水溶媒のゲル濾過により 得られたミセル中のミネラルを結合型，遊離したミネラ ルを吸着型としている，窒素はケルダール法，リンは Fiske \& Subbarow 法により, 全りン(Pw), 無機リン ( $\mathrm{Pi}) ， エ ス テ ル リ ン ~(\mathrm{Pe})$ を測定した，Ca は原子吸光法 によった。クェン酸はピリジン・無水酢酸法によった。 ミセル中の Ca の計算法は，著者らのモデル計算法に上 り，Pi はすべて，コロイド性無機リンとして， $\mathrm{Ca}_{3}$ $\left(\mathrm{PO}_{4}\right)_{2}$ 量を算出し, クェン酸は 2 カルンウムの形で存 在するものとして、 $\mathrm{Ca}_{2}$-citrate 量を算出し, 全 $\mathrm{Ca} よ$ り、これらの Ca を差引いて，カルボキシル基に結合す る-COOCa- 量として示した，カゼイン成分比は， $4 \mathrm{M}$ 尿素・電気泳動とデンシトロールによった。

実験結果・考察 B 型乳に $\gamma$-A を加兄ると，A型 乳に転換した（Fig.1). 水溶媒によるゲル濾過で得たカ ゼインミセルを分析に供したので，イオン結合型の Ca 塩の形態である(Table I, Fig. 2)。B型乳拉よび $\gamma-\mathrm{A}$ 添加の場合ともに，コロイド性りン酸カルシウム $\left[\mathrm{Ca}_{3}\right.$. $\left.\left(\mathrm{PO}_{4}\right)_{2}\right]$ 量は， $\mathrm{pH}$ の上昇とともに增加した， $\gamma-\mathrm{A}$ を添 加すると，ソン酸カルシウムの結合量蛙，い口艺う增加 Lた. $\mathrm{pH} 7.0$ 点（熱不安定化，A型乳枟換）ではこの 


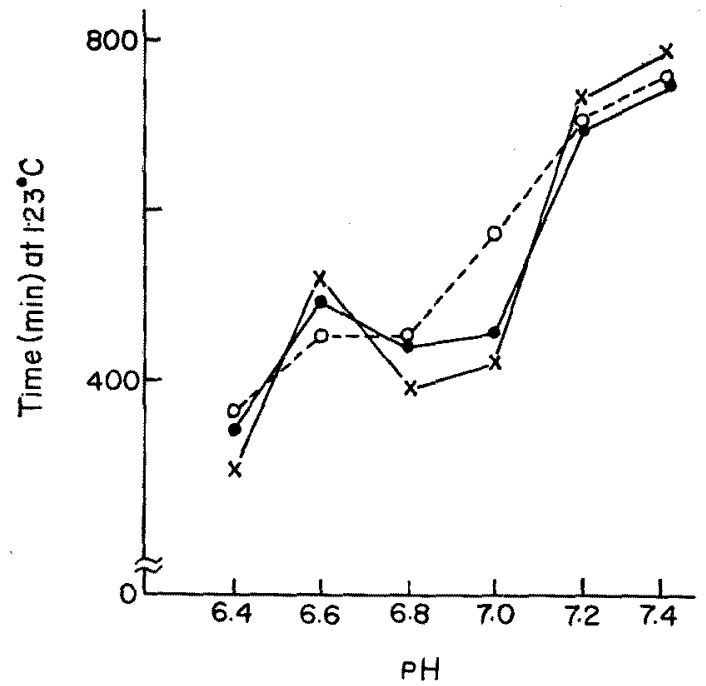

Fig. 1. The pH-Heat Stability of Milk. Type-B milk (O) showed a linear increase of heat stability with the high $\mathrm{pH}$ value. Type-B milk plus $\gamma$-casein A ( ) was changed into type-A milk, although not a typical curve, which was unstable at $\mathrm{pH}$ 6.9. Type-A milk $(x)$ is unstable near at $\mathrm{pH} 6.8$.

Ca 塩の結合量が若干, 減少し, 反対に - COOCa- 量は 增加した。この結果から, セリンリン酸エステルとし て，カルシウム・アパタイト塩の形で結合するりン酸カ ルシウムは，カゼインの分子間の会合を切断する働きが

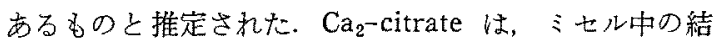
合量が大である汪ど，乳安定化の傾向にあったが，その 役割は不明確であった．Rose(18) によると，アパタイト 塩の構浩のなかで，2価のクエン酸は $\mathrm{H}^{+}$イオンと交換 した形で結合している、ミセル中のカゼイン成分比は Table IIK示した，B型乳では，pH の上显ととるに，

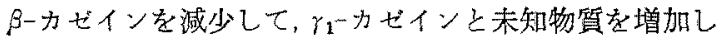

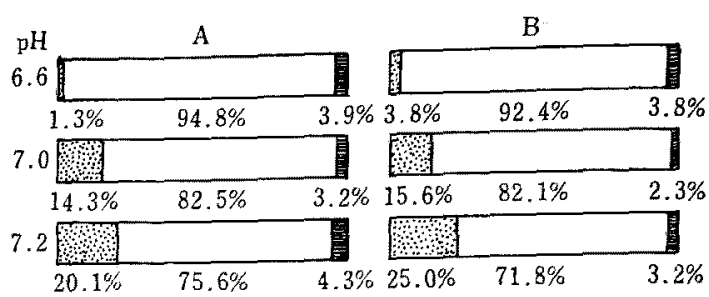

Fig. 2. Effect of $\gamma$-Casein $A$ on the Composition of Calcium Salts in Casein Micelle when Heated at $123^{\circ} \mathrm{C}$. This figure was illustrated from Table I. The content of colloidal calcium phosphate $\left[\mathrm{Ca}_{3}\left(\mathrm{PO}_{4}\right)_{2}\right]$ in casein micelles showed more increased percentages in type- $B$ milk plus $\gamma$-casein A (B) than in type-B milk (A). 파요, $\mathrm{Ca}$ of $\mathrm{Ca}_{3}\left(\mathrm{PO}_{4}\right)_{2} ; \mathrm{Ca}$ of $\mathrm{Ca}_{2}$-citrate ; $\square, \mathrm{Ca}$ of $-\mathrm{COOCa}$ -

た.これは $\beta$ ごー一部, 分解して $\gamma_{1}$ に変化し, この際, 生 成した残りのペプヂド鎖の部分（N末端から28番目をで

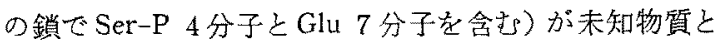
して増加したものと推定された。， $\alpha_{\mathrm{s}}$ と末知物質は相関 的に増加与るので, Ser-P 含量の多い末知物質が $\alpha_{3}$ と 会合し，リン酸カルシウムを結合して、ミセル棈造を安 定にーる役割を果たするのと判断された，pH7.0 点で

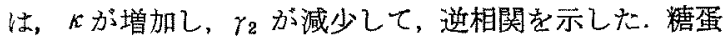

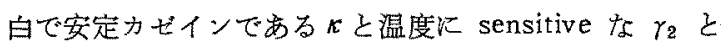
の間のこの $\mathrm{pH}$ 点での相関作用は，おとらく熱安定性に 影響を及ぼしているものと考觉られた，次に，B型乳に $\gamma$-A を添加した場合， $\beta$ は酸性側で， $\alpha_{\mathrm{s}}$ はアルカリ側

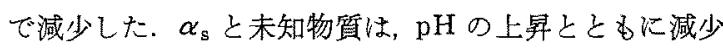
するので，この黹者が同じ举動をして相互作用するが， $r$, とくに, $\gamma_{1}$ と $\gamma_{3}$ が㩆著に增加し，また， $\alpha_{\mathrm{s}}, \beta, \kappa$, rの各力ゼインの間に，何ら，相䦎がないのに，リン酸 カルンウムの結合量隹增加するので,

Table I. Effect of $\gamma$-Casein A on the Composition of Calcium Salts in Casein Micelle when Heated at $123^{\circ} \mathrm{C}$

\begin{tabular}{|c|c|c|c|c|c|c|c|c|c|c|}
\hline \multirow[b]{2}{*}{ Sample } & \multirow[b]{2}{*}{$\mathrm{pH}$} & \multicolumn{8}{|c|}{$\mathrm{mM} / \mathrm{g}$ Casein $\mathrm{N}$} & \multirow[b]{2}{*}{$-\mathrm{COOCa}-$} \\
\hline & & $\mathrm{Ca}$ & $\mathrm{Pi}^{\mathrm{a}}$ & $\mathrm{Ca}_{3}\left(\mathrm{PO}_{4}\right)_{2}$ & $\begin{array}{c}\mathrm{Ca} \text { of } \\
\mathrm{Ca}_{3}\left(\mathrm{PO}_{4}\right)_{2}\end{array}$ & $\begin{array}{c}\mathrm{Ca} \text { except of } \\
\mathrm{Ca}_{3}\left(\mathrm{PO}_{4}\right)_{2}\end{array}$ & Cit. ${ }^{a}$ & $\mathrm{Ca}_{2}-\mathrm{Cit}{ }^{\mathrm{a}}$ & $\begin{array}{l}\mathrm{Ca} \text { of } \\
\mathrm{Ca}_{2} \text { Cit. }\end{array}$ & \\
\hline \multirow{3}{*}{$\mathrm{TBM}^{\mathrm{b}}$} & 6.6 & 3. 08 & 0.02 & 0.10 & 0.04 & 3.04 & 0.29 & 0.41 & 0.12 & 2. 92 \\
\hline & 7.0 & 4.06 & 0.30 & 1.50 & 0.58 & 3. 48 & 0.31 & 0.44 & 0.13 & 3.35 \\
\hline & 7.2 & 3. 48 & 0.36 & 1. 80 & 0.70 & 2. 78 & 0.35 & 0.50 & 0.15 & 2. 63 \\
\hline \multirow{3}{*}{$\begin{array}{l}\text { TBMb plus } \\
\gamma \text {-casein A }\end{array}$} & 6.6 & 2.62 & 0.05 & 0.25 & 0.10 & 2. 52 & 0.24 & 0.34 & 0.10 & 2. 42 \\
\hline & 7. 0 & 3.85 & 0.31 & 1. 55 & 0.60 & 3.25 & 0.21 & 0.30 & 0.09 & 3. 16 \\
\hline & 7.2 & 3. 48 & 0.45 & 2.25 & 0.87 & 2.61 & 0.27 & 0.38 & 0.11 & 2.50 \\
\hline
\end{tabular}

a $\mathrm{Pi}_{\mathrm{i}}$ (inorganic P), Cit. (citric acid), Ca $\mathrm{Ca}_{2} \mathrm{Cit}$. (calcium citrate); b TBM (type-B milk). 
Table II. The Protein Constituent of Casein Micelle Obtained by Gel Filtration of Type-B Milk (TBM) and TBM plus $\gamma$-Casein A on Sephadex G-150 Column

\begin{tabular}{|c|c|c|c|c|c|c|c|c|}
\hline \multirow{2}{*}{ Sample } & \multirow{2}{*}{$\mathrm{pH}$} & \multicolumn{7}{|c|}{$\%$} \\
\hline & & $r_{2}$ & $r_{3}$ & $r_{1}$ & $\beta$ & $\kappa$ & $\alpha_{3}$ & Unknown \\
\hline \multirow{3}{*}{ TBM } & 6.6 & $3.2(100)$ & $2.7(100)$ & $2.0(100)$ & $38.9(100)$ & $9.2(100)$ & $42.6(100)$ & $1.4(100)$ \\
\hline & 7.0 & $1.2(38)$ & $2.1(78)$ & $3.0(150)$ & $36.9(95)$ & 11. $6(126)$ & $43.3(102)$ & $1.9(136)$ \\
\hline & 7.2 & $2.9(91)$ & $2.0(74)$ & $5.9(295)$ & $35.9(92)$ & $7.9(86)$ & $43.4(103)$ & $2.0(143)$ \\
\hline \multirow{3}{*}{$\begin{array}{l}\text { TBM plus } \\
\gamma \text {-casein } A\end{array}$} & 6.6 & $1.4(100)$ & $2.1(100)$ & 4. $1(100)$ & $32.3(100)$ & $9.6(100)$ & $48.2(100)$ & $2.3(100)$ \\
\hline & 7.0 & $4.4(314)$ & $4.0(191)$ & $4.8(117)$ & $35.5(110)$ & $8.4(88)$ & $42.4(88)$ & $0.5(22)$ \\
\hline & 7.2 & $2.9(207)$ & $4.4(210)$ & $5.8(142)$ & $35.4(110)$ & $9.6(100)$ & $40.0(83)$ & $1.7(74)$ \\
\hline
\end{tabular}

は, 複雑なカゼイネイト複合体を形成するものと推定さ れた。また， した原因结，pH7.0 点でのミセル中の未知物質の減少 に起因寸るリン垔カルシウムの結合量の減少拈よび安定 カゼインである $k$ の減少によるるのと判断されたな

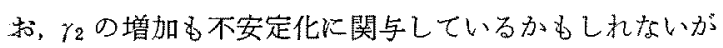
明瑔ではない。

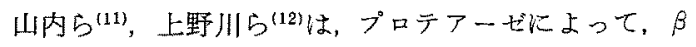
から TS およぴ R火分解寸ることを認めている。 Tessier $ら^{(19)}$ は， $\beta$-ラクトグロブリンがA型乳から B 型乳

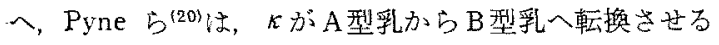
ことを認如ている。山内ら 211 は、エロイド相中の $\mathrm{Ca}$ 添加 Ca イオンの相互交換率を調べた結果， $100^{\circ} \mathrm{C} ， 30$ 分の加熱により, 可溶性 $\mathrm{Ca}$ の一部が若干、コロイド相

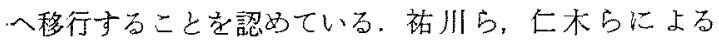
之，UHT 殺菌乳，隇菌乳可溶性 $\mathrm{Ca}, \mathrm{P}$ 仗, $10 \% \mathrm{C}$ $13 \%$ 壮減少し ${ }^{(22)} ， 2 \sim 4^{\circ} \mathrm{C} ， 48$ 時間の椧蔵で, 任とん どもとの值にるどる(23)しいう. Payens ${ }^{(24)} に よ る と ， \alpha_{\mathrm{s}}$ は折りたたをれた潄造で存在し、リン酸カルシウムは 大部分, 三七ルの表面に存在子るとい5. Morr ${ }^{(25)}$ $\operatorname{Rose}^{(28)}$ は、 $\beta$ $\beta$ ポリーに $\alpha_{\mathrm{s}}$ の一部が会合し、 コロ イド性りン酸カルシウムがミセルの構造を保持し， $\mathrm{Ca}$ イオンにより，サブニニットはにの存在しない部分で㠜 集し，ハがミ七ルの表面にあ狆ば㧕制するという，本実

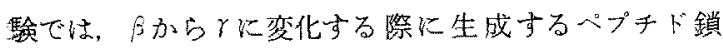
(Ser-P 4 分子含有) が， $\alpha_{\mathrm{s}}$ と举動をとbにして， イド性リン酸カルシウムの結合に関与すること， B型乳 に ケ-A 老添加すると，複雑なカゼイネイト複合体を形 成して，リン酸カルシウムの結合量を增加させることな どが琶められた。をた， の $\gamma\left(\gamma_{1}, \gamma_{2}, \gamma_{3}\right)$ の結合量を增加するが，円盾光二色性 (CD) 曲線に徽妙な変化があり，UV スペクトルにも変
化があった， $\beta$ から $\gamma_{1}$ 生成の際の未知物質は $\beta$ 米末 端から 28 番目までのペプチド鎖であるが，この部分の 短い鎖中心《，Ser-P の4分子と Glu の7分子を含儿 でいるので，前者は、リン酸カルシウムの結合，後者 は，グルタミン酸のカルボキシル基が水素結合あるいは イホン結合をしや市い物質である。括るらく， $\alpha_{9}$ と会 合すると判断された。亦た， $\gamma$-A の添加だ， $\alpha_{\mathrm{s}}$ が減少 するのは， $\alpha_{\mathrm{s}}-\gamma$ 複合体を形成して，分子量の小さい複合 体となって，ミ七ルから遊離なるためであるら。なお， 不明の点も多いが，詳細は今後の研究に待らたい。

(1) D. Rose: J. Dairy Sci., 44, 430 (1961).

(2) D. Rose:J. Dairy Sci., 44, 1405 (1961).

(3) H. Tessier and D. Rose : Dairy Sci., Abstr., 47, 1047 (1964).

(4) W. H. Sweetsur and J. C. D. White: J. Dairy Res., 41, 349 (1974).

(5) W.M.Sweetsur and J. C. D. White: J. Dairy Res., 42, 57 (1975).

(6) W. M. Sweetsur and J.C. D. White: $J$. Dairy Res., 42, 73 (1975).

(7) W. M. Sweetsur and D. D. Murir: $J$. Dairy Res., 47, 327 (1980).

(8) D. B. Hylop and P.F. Fox: J. Dairy Res., 48, 123 (1981).

(9) P. F. Fox and P. A. Morrissey : J. Dairy Res., 44, 627 (1977).

(10) W. N. Eigel and H. E. Randol : J. Dairy Sci. 59, 203 (1976).

(11) K. Yamauchi and S. Kaminokawa : Agric. Biol. Chem., 36, 249 (1972).

(12) S. Kaminokawa and K. Yamauchi: Agric. Biol. Chem., 36, 255 (1972).

(13) W. G. Gordon and M. L. Groves: J. Dairy Sci., 58, 574 (1975).

(14) M. L. Grove and W. G. Gordon: Biochim. Biophys. Acta, 194, 421 (1968).

（15）電気泳動学会編：「電気泳動実娩法」，文光堂， 1964, p. 264 . 
(16) M. L. Groves and C. A. Kiddy:Arch. Biochem. Biophys., 126, 188 (1969).

（17）宮辺豊紀，森川康文：農化，50，447 (1976),

(18) D. Rose: $J$. Dairy Sci, 48, 139 (1965).

(19) H. Tessier and D. Rose : J. Dairy $S c i$, 50, 1744 (1967).

(20) G. T. Pyne and T.C. A. McGann : J. Dairy Res., 27, 9 (1960).

(21) K. Yamauchi and Y. Yoneda: Agric. Biol.
Chem., 41, 2395 (1977)

（22）祐川金次郎，村沢久司，佐↔木正人：策養亡食 橿, 34, 445 (1981).

（23）仁木 達，桜井俊二，土肥 達: 雪印乳業酪農 研報，57, 1 (1959).

(24) T. A. J. Payens: J. Dairy Sci., 49, 1317 (1966).

(25) C. V. Morr : J. Dairy Sci., 50, 1744 (1967).

(26) D. Rose : Dairy Sci., Abstr., 31, 171 (1969). 